\title{
Productivity and Efficiency in the Development of the Swedish Construction Sector
}

\author{
Anne Landin', Mats Öberg² \\ ${ }^{1}$ Department of Construction Sciences, Lund University, Lund, Sweden \\ ${ }^{2}$ Department of Building and Environmental Technology, Lund University, Lund, Sweden \\ Email: anne.landin@construction.Ith.se
}

Received 28 March 2014; revised 28 April 2014; accepted 20 May 2014

Copyright (C) 2014 by authors and Scientific Research Publishing Inc. This work is licensed under the Creative Commons Attribution International License (CC BY). http://creativecommons.org/licenses/by/4.0/

(c) () Open Access

\begin{abstract}
The measurement of productivity and efficiency of activities in the Swedish construction sector is examined. Understanding past and present levels of productivity is necessary to steer emerging and future developments aimed at increasing efficiency of construction. The absence of purposeful measurement methods and tools for determining current and targeted levels of productivity creates confusion for clients, designers, constructors and end-users, who are unable to make confident forecasts of costs and revenues or benefits over project life cycles. The findings of an investigation using panels of expert practitioners guided by senior researchers revealed shortcomings in the understanding of factors of driving productivity as well as uncertainty over where improvements might be achieved. The significance of the findings is that methods and tools must be calibrated to current and emerging construction practices and their technical bases rather than continuing with measurements that were conceived for earlier processes and products. The paper concludes with an outline of further research aimed at improving self-learning in regard to both process and product as part of a broad response to raising efficiency through innovation.
\end{abstract}

\section{Keywords}

Productivity, Efficiency, Measurement, Innovation Models, Construction

\section{Introduction}

Construction is considered less progressive than other industrial sectors (see, for example [1] [2]). The need for improvement in terms of the efficiency and effectiveness of work is often discussed, for instance in programmes 
of continual improvement [3] [4] or in generative learning [5]. Improvements can concern a process or be of a purely technical nature, and a variety of factors are considered to be influential in bringing about improvement. A corollary is that if the most critical factors can be identified, steps can be taken to increase efficiency and effectiveness. Even so, necessary changes to practice can take time to become embedded within a work environment in which few stakeholders are able to exercise full control over the process. Consequently, some technical innovations diffuse rapidly to become integrated into everyday practice while others fail. In this context, several factors have been identified as innovation enablers. One such factor is client support [6], where process operation time and customer satisfaction are used as indicators of efficiency and effectiveness respectively. Greater efficiency should be expected to lead to increased effectiveness, which can be measured in terms of, for example, improved customer satisfaction and better value for money. A variety of measures exist to determine levels of efficiency and effectiveness, thus providing reliable impressions of change in different areas of the sector.

Hekkert et al. [7] discuss how the progress of a sector depends on the implementation of new developments ${ }^{1}$, including technical innovations, as well as barriers and opportunities. Policies and regulations can support or frustrate would-be development [7] and the role of government seems to be an important factor influencing the development of contractors in particular [8]. There is strong interest on the part of stakeholders [9] in factors influencing efficiency and effectiveness, particularly those relating to productivity ${ }^{2}$. Furthermore, since buildings are long-lived, poor government-inspired policies could, for instance, incur heavy penalties for many decades into the future [10], with the potential to affect people and organizations negatively. Measures of efficiency and effectiveness are therefore of importance in tracking progress. A Swedish study confirms that, in the main, key actors in the sector are motivated to measure and keep track of their own efficiency [9].

A number of studies have attempted to measure efficiency through a focus on productivity. These have, in the main, been limited in scope and have focused mostly on repetitive operations (see, for example [11] [12], and [13]. A case study conducted in Florida [14] serves as a useful example of the difficulties inherent in measuring performance, in this case with respect to contractors. The greatest challenge was unforeseen site conditions and these had a direct impact on productivity. The seemingly low level of cost efficiency of the construction sector is yet another factor and is considered to be largely attributable to allocative inefficiency, i.e., an inappropriate mix of input factors, rather than technical inefficiency [15].

Another way of approaching improvement is to study defects that arise in construction, many of which are described in Hammarlund and Josephson [16] and Mills et al. [17]. Other studies have attempted to clarify the significance of various phenomena in the construction process. Examples of such phenomena are management and the organization's role [18], the impact that authorities and their policies have on the construction sector [10] and the importance of a particular and systematic approach to construction [19].

In the study on which this paper is based, the aim has been to explore productivity issues to find ways of relating them to improvement on the sector level. The purpose of this paper is to examine factors that stimulate development as a driver of increased productivity and, hence, greater efficiency that, in turn, leads to improved effectiveness.

\section{Different Approaches to Measuring Efficiency}

The most common way of classifying the efficiency of an industrial sector, which is used generally across the industry and to compare sectors, is based on the UN-defined Standard Industry Classification (SIC). This classification divides a country's business and operations into a number of classifications, for example 1540: General Building Contractors-Nonresidential Buildings and 1700: Construction-Special Trade Contractors. The statistics which form the basis of national development programmes for construction are structured in accordance with SIC [20]. From such statistics we can learn something about comparative efficiency, but understanding on a deeper level is not possible.

The construction sector has a large number of specialized areas and disciplines and many of them are based on repetitive processes. Flow processes are commonly considered in terms of time, while construction operations are considered in terms of productivity. Activities on construction sites continue to be labour-intensive for most forms of construction and so productivity cannot be considered without regard to the role of labour as the

\footnotetext{
${ }^{1}$ Development in this context is defined as the progression of individuals and organizations towards higher levels of efficiency and effectiveness as might be achieved through, for instance, innovative processes and products.

${ }^{2}$ In this context and for the purpose of this paper, productivity refers to the throughput or outputs of work; and the rate at which work is produced is a measure of its efficiency.
} 
primary resource. In a competitive construction environment, which tends to be the norm rather than the exception, there is pressure to reduce the base cost and, therefore, on-site labour is a prime target. Moreover, efficiency gains here can translate directly into profits. Gouett et al. [21] report on the development of a workforce assessment method called activity analysis, which is described as a continual productivity performance improvement process, and the aim of which is to measure time spent by workers on-site and thereby identify productivity inhibitors. At this point, it is not possible to confirm the reliability of the method, but it appears to offer the potential for useful insights into productivity and efficiency.

Other studies on productivity, for example Dunlop and Smith [13] and Court et al. [11], have investigated highly-defined operations based on the philosophy of lean construction. However, even the most common repetitive operations create their own difficulties in terms of measurement. One example is the placing concrete, where the duration of the concrete pour can be interpreted in different ways. It can be taken as the time from when the first load of concrete is batched or the time from when the first concrete is discharged into the formwork. Each will give a different figure for productivity, yet both can be seen to be relevant [13]. Studies of this kind are of use in understanding the construction process but, at the same time, they attempt to shift the emphasis away from construction project management per se. In this connection, it is apparent that the project manager is viewed as another consultant in a complex supply chain. It seems necessary, therefore, to find measurements of performance that consider the detail of construction activities and which can provide an appropriate basis for evaluating the impact of construction project management. Brown and Adams [18] used conventional economic analysis tools to create an evaluation framework to determine the impact of construction project management. The study was performed on construction projects in the UK and the finding was that projects do not perform as expected in relation to three primary criteria for performance evaluation: time, cost and quality. It is not clear from their study if the finding was due to project management not functioning well enough or, perhaps, the principles of project management were not adapted sufficiently to the construction context. Swarup et al. [22] present a holistic model to assess delivery metrics in relation to project organizational characteristics. In that research, the results with respect to quantitative criteria, i.e., time, quality and cost, are linked to a qualitative assessment of aspects such as commitment by project participants. This more recent attempt at measuring productivity shows promise of new avenues that might lead to a reform of the rather "hit and miss" approach to measurement that focuses on simple indicators whose bases might have changed during execution of the project.

\section{Construction Innovation ${ }^{3}$ Model}

Total productivity has a significant impact on the drivers of future competition [23] and it is the concept in economic theory that most closely corresponds to the measurement of efficiency in development and so was chosen as the basis for a construction innovation model. Total productivity is defined as the relationship between input and output. There are two alternative approaches that have a relationship to output/input measurements, namely customer satisfaction and annual costs. Some of the measures proposed later in this paper are inspired by these alternative approaches. In this connection, records of the development of efficiency over time have been studied, with appropriate methods for measuring efficiency discussed by Landin and Öberg [4].

An innovation can relate to an activity or a product at the "micro level" rather than the "macro level" such as an industry sub-sector, firm or project [24]. The proposed innovation model must, however, be able to span from detail to sub-sector. Technical or process change arising from an innovation can lead to large improvements on the micro level, but may not necessarily provide any significant productivity increase on the macro level.

Bröchner and Olofsson [25] have developed a generic model that broadens the definition of productivity through the incorporation of measures of efficiency. The model leads to an input/output ratio based on quantitative and qualitative measurements. Ten basic requirements for efficiency measures have been defined [2]:

1) Usability - in relation to strategic goals;

2) Low cost of data collection and coordination;

3) Reliability-regardless of who is collecting the data and when data are collected, and accurately defined data collection methods with appropriate sampling techniques;

4) Validity-measuring the dimension of what we really want to understand;

\footnotetext{
${ }^{3}$ Construction Innovation is also the name of an on-going Swedish R\&D programme launched by VINNOVA (The Swedish Governmental Agency for Innovation Systems) and a number of organizations in the construction sector aimed at strengthening productivity. The research reported here falls within the scope of this programme.
} 
5) Compatibility-with other quantitative metrics within the same system with other systems-in other industries, other countries - not least official statistics on the industry level;

6) Opportunities to develop and analyze time series, including the choice of periodicity;

7) Short time between data collection and data usage;

8) Existence of strong incentives to deliver data;

9) Weak (or no) side-effects on behavior of the data is used for controlling selection or monitoring of individuals and businesses;

10) Little (or no) risk of leakage of competitive business-critical information.

The model will be applied within the Construction Innovation programme in the process of selecting projects to be funded and, later, to assess project results. In this connection, three focus areas have been proposed: information technology, innovative processes and sustainable development. In order to secure objective evaluation and comparison of projects within this large scope, elements of the model will be utilized in the selection process. It is expected that feedback from experience of its application will enable the model to be further developed as a support for decision-making.

\section{Methodological Approach}

The first phase of the Construction Innovation research action has been concluded with methods for measuring efficiency defined and tested. During this phase, six groups were set up to investigate various types of construction: bridges, multifamily housing, office buildings, highways, concrete repairs and HVAC renovation in multifamily housing. Each group was formed of practitioners with long experience in the sector, and senior researchers from disciplines within construction sciences. The groups met on a regular basis in workshops to compare and, where necessary, to reconcile any differences in the results. The findings reported in this paper originate from the groups concerned with office buildings and multifamily housing.

The initial challenge was to find performance indicators that could clearly and equitably portray the efficiency of the construction sector over time. Performance indicators were studied for each type of construction in order to determine the most appropriate factors. Factors that are easy to measure are not always the correct ones. It is therefore important to analyze critically what should and could be measured. There was a need to find indicators that could be used to measure both forwards and backwards in time. The practitioners in the groups were particularly intent on identifying improvements that could be addressed by research applied to the execution phase of the construction process. As the research progressed, the emphasis changed from measurement of input and output parameters to a more reflective approach. The consequence was that a prospective approach based on scenario analysis was considered [26], which could benefit the sector in a proactive manner, instead of recording past events for future analysis. Scenario generation is, however, highly qualitative and the influence of one factor on another is often a subjective judgment.

Expert panels [27]-[29] were mobilized by the group concerned with office buildings, with members drawn from outside the group. The criteria for the selection of experts were determined on the basis of those whose experience and insights were considered to offer the greatest potential input to the work programme. The panel included 2 architects, 4 clients, 2 contractors, 2 property developers, and all were invited to offer different forecasts for the construction sector. The panels were also used to check model inputs and to adjust outputs considering factors not previously encountered. They were then encouraged to revise their forecasts in the light of others' opinions. It was expected that during this process, collective responses would converge on a consensus forecast that would be more accurate than individual forecasts by the experts working alone [29] [30]. The method is similar to the Delphi technique; however in this study, we did not make use of additional feedback rounds in order to reach consensus amongst the experts. It was considered important that the richness of opinions contributed to the outcome of the study and so we wanted these to be articulated and retained.

The central task was to gain as deep an understanding as possible of the phenomenon being studied while, at the same time, providing clarity in regard to the context within which the problem of productivity is set. The research design was based on sourcing qualitative data from the expert panel followed by a number of interviews and workshops in order to develop a holistic understanding of the phenomenon.

For the office building study, the main research technique selected for data collection was qualitative and iterative, based on in-depth, semi-structured interviews using a prepared guide. These were conducted with leading actors in the sector and produced a lot of useful data. The approach involved encouraging interviewees to dis- 
cuss the topics they considered most relevant within the framework of the interview guide. Interviews generally took between one and two hours. Material that appeared particularly representative and pertinent was then selected for further analysis.

The interview guide covered nine topics: architecture, environment, indoor climate, security and accessibility, flexibility, technique, economy, construction and operating processes and, finally, a question about perceived critical development issues. The questions were designed to capture data regarding efficiency in the construction sector over time. The data were analyzed by the authors and then the findings were examined by the expert panel to identify specific development needs and trends to provide a baseline for a complete model and method for measuring efficiency.

\section{Results}

\subsection{Model for Measuring Efficiency}

The model was designed to measure efficiency for office buildings and multifamily housing (see Table 1). Annual costs were calculated as part of a life cycle cost appraisal. To address improvement with respect to customer value, the annuities included both input, which corresponds to life cycle costing, and output corresponding to revenues over the life cycle [31].

Since the basic idea was to compute annuities, assumptions had to be made about discount rates, life expectancy, future price development of energy, water and other operational resources, and end-user behavior. If annual cost calculations were to correspond with total productivity measurement, the implied discount rate should be determined first. This might be higher than is normally assumed in annual cost estimates, especially when the customer is a public client with different investment and operating budgets.

The selected aspects in the model in Table 1 were deemed to be of strategic importance by the groups. The model can be expanded to cover other aspects and was, in fact, tested at the product level in a study comparing six different types of façade [32]. The study concluded that it was relatively easy to expand the basis for evaluation and thereby provide better support for strategic decisions in regard to development, as well as retrospective evaluation of efficiency. It was, therefore, considered feasible to measure the impact on a higher level, for instance on a whole building or on a group of buildings.

The efficiency of new developments can thus be expressed by an output/input ratio on the aggregated level amended by an energy output/input ratio and selected output scores.

Table 1. Model for measuring changes in efficiency for office buildings and multifamily housing.

\begin{tabular}{|c|c|c|}
\hline Aspect & Unit & Remark \\
\hline \multicolumn{3}{|l|}{ OUTPUT } \\
\hline Usable area & $\mathrm{m}^{2}$ & Revenue area \\
\hline Reduction of future energy use & $\mathrm{kWh} / \mathrm{m}^{2}, 50$ years* & Related to the minimum requirements according to current norm \\
\hline Comfort for users & Points & $\begin{array}{c}\text { Sound, lights, indoor temperature, air quality related to selected } \\
\text { reference values (CEN, 2011) }\end{array}$ \\
\hline Architectural quality & Points & Criteria applied in evaluation models for architectural competitions \\
\hline Flexibility & Flexibility ratio (\%) & $\begin{array}{l}\text { Possibility for future changes according to building flexibility model according } \\
\text { to Saari and Heikkilä (2003) or adjustability according to CEN (2011) }\end{array}$ \\
\hline \multicolumn{3}{|l|}{ INPUT } \\
\hline Production cost per area & $\mathrm{SEK} * * / \mathrm{m}^{2}$ & Total cost of construction per revenue area \\
\hline Energy used for production & $\mathrm{kWh} / \mathrm{m}^{2}$ & $\begin{array}{l}\text { Energy used for production and transport of building } \\
\text { materials and for building site }\end{array}$ \\
\hline \multicolumn{3}{|r|}{ AGGREGATED LEVEL } \\
\hline \multicolumn{3}{|l|}{ OUTPUT } \\
\hline Annual revenue per revenue area & $\mathrm{SEK}^{* *} / \mathrm{m}^{2}, 50$ years$*$ & Financial value according to CEN (2012) \\
\hline \multicolumn{3}{|l|}{ INPUT } \\
\hline Annual costs per revenue area & $\mathrm{SEK}^{* *} / \mathrm{m}^{2}, 50$ years$*$ & Life cycle cost according to CEN (2012) \\
\hline
\end{tabular}

*Time horizon may be adjusted according to subject of evaluation. **Swedish krona. 


\subsection{Expert Inquiry}

With a retrospective view of the past 40 years, the study revealed significant changes and improvements of both product and production. These can be expressed as increased output of office work per square metre and longer working hours. Resource use, especially energy, in the operation of buildings is lower nowadays as Figure 1 illustrates. Factors such as energy use can be measured using holistic performance indicator methods, but they are not reflected in the traditional approach for measuring the efficiency of an industrial sector.

Another of the more significant changes is the increasing complexity of office buildings. Despite the challenges faced by designers, it seems that they can be reluctant to engage with subcontractors and suppliers sufficiently to benefit from their competence and commitment. A common example referred to by the experts was partnering projects, where the client and main contractor form a collaboration which, it is expected, will trigger fruitful innovative thinking and improved project outcomes. Subcontractors and suppliers are, however, seldom included in this partnering process and valuable potential input to the project is not utilized. It seems as though the construction sector has yet to accept that it has become a knowledge-intensive sector, where knowledge transfer must be taken far more seriously and considered systematically [33].

The complex of construction activity, which is not confined to major or special projects, places increasing demand on the need for effective information transfer and knowledge creation. A key factor in gaining competitive advantage is the effective management of knowledge resources. Evaluating knowledge management practices is considered to be one of the most important challenges facing companies in the business environment today [34]. Indeed, Kale and Karaman have developed a model that can be used by construction companies as a performance measurement tool to evaluate knowledge management practices. Sustainable, high-performance buildings require competences from multidisciplinary teams. Designers and constructors should therefore seek ways of establishing a more integrated team environment throughout the delivery process [22].

The scope of the design process is likely to change in the future, according to the respondents in our study, due largely to increased demands regarding the functions demanded in buildings. One wish was that the design should be based on an interdisciplinary approach that includes end-users, which is confirmed in work by Pemsel et al. [35].

Our study collected significant evidence of an inability to manage and exploit knowledge and experience. One example is the modular construction method that was commonplace during the 1960s and 1970s. This facilitated the open building principle [36] [37]. The most significant example is the Garnisonen office building in Stockholm constructed in 1971. The project demonstrated the general and flexible office planning toolkit, based on prefabricated building parts, developed by one of Sweden's leading architects at that time and commissioned by the Construction Authority Board. The basic philosophy for achieving long-term flexibility was to decouple the parts that can remain constant over the building life time from those that require change because of different uses [38]. A typical example is the separation of building services installations and building structure as shown in Figure 2, enabling access to services and changes in the configuration of space.

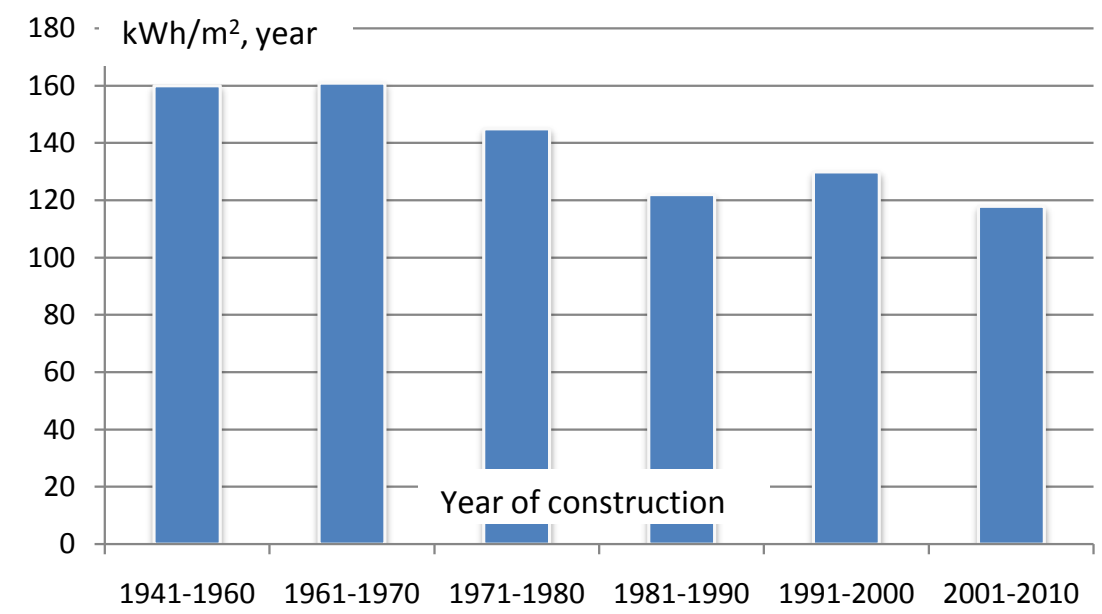

Figure 1. Energy use for heating and hot water in Swedish office buildings by year of construction (SEA, 2011). 


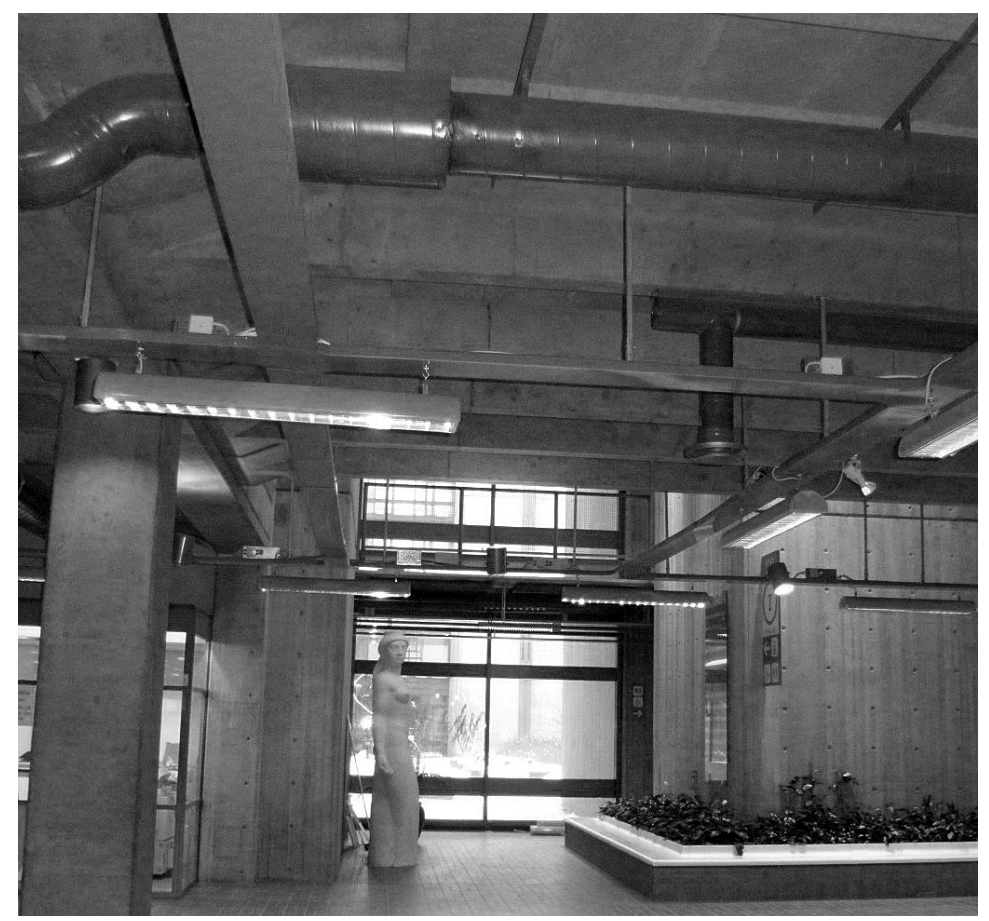

Figure 2. Example decoupling of parts and systems.

A distinct advantage of open modular construction is that it covers design, purchasing and production methods as well as servicing and maintenance of the building. Present day proponents of open modular construction are rare and, with few exceptions, limited to specific internal company systems.

Another example from our study is the extremely slow introduction of building information models. During the early 1980s, CAD was introduced, including multi-disciplinary multi-layer drawings, integration of design calculations (for example, reinforcement drawings) and automatic quantity take-offs. The Construction Authority Board initialized work to define a common standard for neutral building information models in the late 1980s as reported by KBS [39]. More than 20 years later, BIM is still not fully implemented in construction and facilities management, although this situation is expected to change rapidly [40] with the development of national and international standards.

In the case of the office building, the total area per employee has decreased over time from the previous 20 square meters to 10 square meters currently. There is reason to believe that this trend will continue, albeit at a much reduced rate, due to changes in office culture and required reductions in operating costs. Individual offices with windows have given way to open spaces with large windows and deeper buildings on plan. The expert panel agreed on the improved standard of today's office building, for example with regard to accessibility, acoustic insulation and energy performance. These factors must be taken into account in any evaluation of the sector's performance over time.

Figure 3 shows the construction cost of office buildings with reference to general national cost indices since 1992 [41]. Note that the increase in costs for building service installations during the latter part of the period is particularly emphasized for offices having a "high specification". Technological change is largely driven by the growing demand for control over the indoor climate whilst, at the same time, reducing energy use. There is potential for development leading to innovation with respect to materials, systems, modeling and control, which can significantly improve capacity and economy. In the future, services installations should be considered much more systematically and be integrated harmoniously with the building and operations. The thermal insulation of the building "shell" has doubled since the early 1970s, but in other respects the technology of structure and fabric has not undergone any significant change.

Cycles of change within organizations have become shorter while, at the same time, demand for resources has risen. Leases have become shorter too, requiring higher flexibility on the part of the building to meet potential new uses. This flexibility applies particularly to design and supply of heating, cooling and IT. Against a back- 

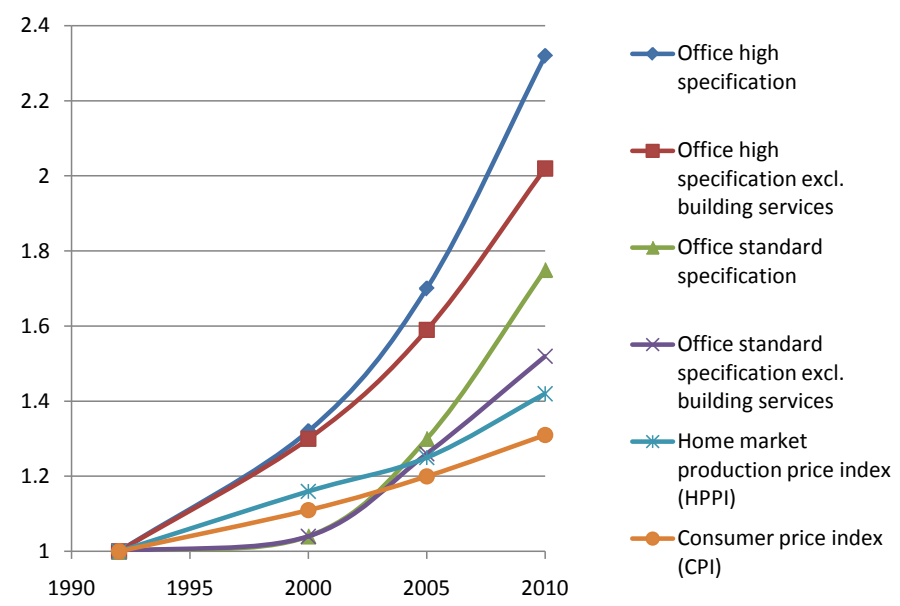

Figure 3. Development of office construction costs and general cost indices.

ground of sustainable development, it is unacceptable that technically-sound office buildings should be demolished because they cannot meet the current demands of tenants. Flexibility and adaptability of buildings are therefore critical factors. A recurring remark from the experts was that more flexibility and adaptability of structures and systems will be expected by clients.

There are several suggestions for improvement that are not being applied as standard procedures in the sector. These are supported by the literature, which reveals that knowledge generated within projects is mostly limited to individuals [20] [42]. Several studies have highlighted the need to understand complexity factors applicable to construction (see, for example, Dubois and Gadde [43] and Hossain [44]). Actors in the construction process have to deal with uncertainties and interdependencies, as well as inefficiency of operations in their daily work. A high level of coordination among all actors from the design office to the construction site throughout the project is necessary as a counter to these influences.

The expert panel noted many difficulties and nuances that must be considered when trying to find performance indicators for construction. A broader measure of efficiency, in addition to measurement alone, has to meet the following requirements.

- Consideration of the wider context by including all phases: design, construction and management.

- Inexpensive and rapid design is not necessarily efficient design from a construction perspective.

- Defining revenue and end-user benefits from the creation and upgrading of the built environment.

- Appreciating public benefit and sustainable development.

- Stimulating the innovative process to produce the lowest life cycle cost solution.

- Utilization of knowledge transfer activities in order to recognize performance that will promote innovation.

- Measuring sector development in an equitable manner.

- Addressing the uncertainties of the future.

The experts agreed that the construction sector's products have changed rapidly over time; that is, the content and performance of buildings have changed significantly. Nonetheless, it is important to understand how different measures of efficiency could contribute to innovation. Increasing the pace of innovation is important, since innovation is a key determinant for long-term economic growth and development. Even so, increasing the pace at the national level is challenging: influencing the innovation direction is even harder [7].

Traditional performance measurement can provide reasonably accurate assessment of innovations and, thus their benefits, if complemented by a life cycle perspective and models to measure end-user satisfaction. A general model with simple, but meaningful, measures can be designed; but in terms of customer value (output value), any model needs to be aligned with the product or process application. An innovation project for a bridge would be difficult to evaluate in comparison with, say, a housing project. In the next phase of the research, a sub-project has been planned to develop measures of efficiency further. In order to avoid basing decisions on retrospective assumptions, the technique of scenario analysis will be combined with the measurement model (see Table 1). 


\subsection{Innovation Projects}

The expert panels identified drivers; ideas for development and their potential for increasing efficiency are summarized in Figure 4. Further discussion of these led to the formulation of two related research initiatives in the form of follow-on research and development projects.

\subsubsection{Self-Learning Office Building}

An office building can be regarded as a complex machine that needs to respond to dynamic operating conditions in order to optimize the environment for the office worker, on the one hand, and cost and energy use, on the other hand. With enhanced technology this could be handled with functional, economic and environmental benefits to follow. The aim of this project is to take a technological leap in building design and operation that will lead to improved indoor environment and make buildings self-sufficient and, ultimately, become producers of energy. The drivers are economy of space and operating costs, function and environment, that is, sustainable development. Energy performance of buildings used to be governed by national building regulations. Today, many clients require higher performance based on business interests and concerns. This issue is particularly pertinent with respect to the major challenge of upgrading existing buildings.

\subsubsection{Self-Learning Building Process}

A recurrent view is that there is doubtful benefit from the collective expertise garnered from a project when almost every project starts from scratch with costly investigations, sub-optimization and risk of repeating previous errors. The aim of this project is to define a new way of utilizing and managing knowledge and experience in a project-oriented and fragmented construction sector. Hekkert [7] stated that "mechanisms of learning are the heart of any innovation process". Slow progress observed in this area is due to the lack of common drivers. Each stakeholder is more interested in optimizing its part of the chain than seeing or seeking the best overall outcome. Proposed innovations in this field are: new interaction and incentive models between actors; models for the evaluation of client satisfaction with emphasis on planning and design; models for the evaluation of the ability of organizations to deliver value for the most appropriate price; new methods for the involvement of clients/ stakeholders; a shift from project-orientation to process-orientation; and a reliable system of experience feedback.

The common denominator for the two projects is a breakthrough in virtual building design and construction (VDC) as part of the basis of a reformed construction process where experience and knowledge in general can be managed more effectively than is the case today. For the self-learning building, information technology is equally critical for success.

\begin{tabular}{|c|c|c|}
\hline \multirow[t]{2}{*}{ Drivers } & \multirow[t]{2}{*}{ Ideas for development } & $\begin{array}{l}\text { Contribution to } \\
\text { increased efficiency }\end{array}$ \\
\hline & & Flexibility \\
\hline Energy efficiency & \multirow{4}{*}{$\begin{array}{l}\text { Energy self-sufficiency } \\
\text { - Energy } \\
\text { capturing } \\
\text { materials } \\
\text { - Energy storage } \\
\text { seasonal/diurnal } \\
\text { - Indoor environment } \\
\text { acoustics, } \\
\text { daylight, air } \\
\text { and indoor } \\
\text { temperature }\end{array}$} & $\begin{array}{l}\text { Building as energy } \\
\text { producer }\end{array}$ \\
\hline Shorter leases & & $\begin{array}{l}\text { Healthy indoor } \\
\text { climate }\end{array}$ \\
\hline Green leases & & $\begin{array}{l}\text { Reformed building } \\
\text { process }\end{array}$ \\
\hline \multirow[t]{2}{*}{$\begin{array}{l}\text { Office working } \\
\text { patterns }\end{array}$} & & Clean technology \\
\hline & & $\begin{array}{l}\text { Intelligent products } \\
\text { and materials }\end{array}$ \\
\hline
\end{tabular}

Figure 4. Development opportunities to meet future requirements for office buildings. 


\section{Conclusion}

Productivity and efficiency in the construction sector are often debated. There have been many attempts from both practitioners and the research community aimed at finding tools to highlight "cause and effect" relationships. Productivity measurement is often linked to an activity's execution and there are many factors that can affect outputs, some of which will be specific to the project environment. The availability of time-series data is valuable, but must be treated in relation to events in a wider context than the construction sector alone. The statistics can become contaminated by outside influences, sometimes unknowingly so. The long life span of buildings compared to most other products is reflected in policies for the long-term benefit of society. Long life also complicates decision-making as there are large external uncertainties. The policies for construction should therefore be aimed at a more strategic level of decision-making. What is needed is the better control over the production of resource-efficient buildings. The difficulty is to identify which indicators are needed and how the input data for these should be treated. For this purpose, we have applied a simple model to aid decision-making in development. The results suggest that the model offers a reliable basis for determining changes in efficiency at the project level that can be used to inform design decision-making. At the macro level, the challenge for the sector is to bring about a development-oriented process that continually increases efficiency in the broad sense away from the existing fragmented and project-oriented business structure characterized by a large number of competing firms. Two related research projects have been identified by the expert group: the self-learning office building dealing with energy performance and indoor climate, which is focused on technical issues; and the self-learning building process, which is process-oriented and based on a development-inspired business structure. These will be used to further test and refine the model as it becomes embedded in practice.

\section{References}

[1] Timmer, M.P., Inklaar, R., O’Mahony, M. and Ark, B. (2011) Economic Growth in Europe. Cambridge University Press, Cambridge, 18-45.

[2] Bröchner, J. (2010) Effektivitetsmått för byggsektorn—mätfrågor (Efficiency Measurements for the Construction Industry-Measurement Issues). Samhällsbyggaren, 3, 42-44.

[3] Smyth, H. (2010) Construction Industry Performance Improvement Programmes: The UK Case of Demonstration Projects in the "Continuous Improvement” Programme. Construction Management and Economics, 28, 255-270. http://dx.doi.org/10.1080/01446190903505948

[4] Landin, A. and Öberg, M. (2010) Resultat från bygginnovationens analysgrupper för flerbostadshus och kontor (Results from Building Innovation's Analysis Groups for Apartment Buildings and Offices), Samhällsbyggaren, 6.

[5] Kululanga, G.K. (2009) Construction Process Improvement through Cognitive Power under Team Generative Learning. Engineering, Construction and Architectural Management, 16, 307-324. http://dx.doi.org/10.1108/09699980910970815

[6] Gambatese, J.A. and Hallowell, M. (2011) Factors That Influence the Development and Diffusion of Technical Innovations in the Construction Industry. Construction Management and Economics, 29, 507-517. http://dx.doi.org/10.1080/01446193.2011.570355

[7] Hekkert, M.P., Suurs, R.A.A., Negro, S.O., Kuhlmann, S. and Smits, R.E.H.M. (2007) Functions of Innovation Systems: A New Approach for Analyzing Technological Change. Technological Forecasting and Social Change, 74, 413-432. http://dx.doi.org/10.1016/j.techfore.2006.03.002

[8] Ofori, G. and Lean, C.S. (2001) Factors Influencing Development of Construction Enterprises in Singapore. Construction Management and Economics, 19, 145-154. http://dx.doi.org/10.1080/01446190150505072

[9] Olander, S. and Widén, K. (2010) Measuring Change in a Sector-Credit Case SE06. Danish Building Research Institute, Aalborg.

[10] Barrett, M. (2009) Policy Challenges for Building Stocks. Building Research and Information, 37, 201-205. http://dx.doi.org/10.1080/09613210802645841

[11] Court, P.F., Pasquire C. and Gibb. A. (2009) A Lean and Agile Construction System as a Set of Countermeasures to Improve Health, Safety and Productivity in Mechanical and Electrical Construction. Lean Construction Journal, 61-76.

[12] Court, P.F., Pasquire C., Gibb, A.G.F. and Bowe, D. (2008) Modular Assembly in Health Care Construction-A Mechanical and Electrical Case Study. Proceedings of 16th Annual Conference of the International Group for Lean Construction (IGLC-16), Manchester, 521-531. 
[13] Dunlop, P. and Smith, S.D. (2004) Planning, Estimation and Productivity in the Lean Concrete Pour. Engineering, Construction and Architectural Management, 11, 55-64. http://dx.doi.org/10.1108/09699980410512665

[14] Minchin, R.E., Lewis, D.W. and McLeod, L. (2011) Improving Productivity on a Troubled Bridge Project. Journal of Construction Engineering and Management, 137, 364-371. http://dx.doi.org/10.1061/(ASCE)CO.1943-7862.0000291

[15] You, T. and Zi, H. (2007) The Economic Crisis and Efficiency Change: Evidence from the Korean Construction Industry, Applied Economics, 39, 1833-1842. http://dx.doi.org/10.1080/00036840600690199

[16] Hammarlund, Y. and Josephson, P.E. (1991) Sources of Quality Failures in Building. Proceedings of European Symposium on Management, Quality and Economics in Housing and Other Building Sectors, Lisbon, 30 Spetember-4 October 1991, 671-679.

[17] Mills, A., Love, E.D. and William, P. (2009) Defect Costs in Residential Construction. Journal of Construction Engineering and Management, 135, 12-16. http://dx.doi.org/10.1061/(ASCE)0733-9364(2009)135:1(12)

[18] Brown, A. and Adams, J. (2000) Measuring the Effect of Project Management on Construction Outputs: A New Approach. International Journal of Project Management, 18, 327-335. http://dx.doi.org/10.1016/S0263-7863(99)00026-5

[19] Delgado, D.J. and Aspinwall, E. (2010) A Framework for Building Quality into Construction Projects. Total Quality Management \& Business Excellence, 21, 725-736. http://dx.doi.org/10.1080/14783363.2010.483089

[20] Winch, G. (2003) How Innovative Is Construction? Comparing Aggregated Data on Construction Innovation and Other Sectors-A Case of Apples and Pears. Construction Management and Economics, 21, 651-654. http://dx.doi.org/10.1080/0144619032000113708

[21] Gouett, M.C., Haas, C.T., Goodrum, P.M. and Caldas, C.H. (2011) Activity Analysis for Direct-Work Rate Improvement in Construction. Journal of Construction Engineering and Management, 137, 1117-1124. http://dx.doi.org/10.1061/(ASCE)CO.1943-7862.0000375

[22] Swarup, L., Korkmaz, A. and Riley, D. (2011) Project Delivery Metrics for Sustainable, High-Performance Buildings. Journal of Construction Engineering and Management, 137, 1043-1051. http://dx.doi.org/10.1061/(ASCE)CO.1943-7862.0000379

[23] Rathore, A., Mohant, R.P., Lyons, A.C. and Barlow, N. (2005) Performance Management through Strategic Total Productivity Optimisation. International Journal of Advanced Manufacturing Technology, 25, 1020-1028. http://dx.doi.org/10.1007/s00170-003-1936-z

[24] Huang, A.L., Chapman, R.E. and Butry, D.T. (2009) Metrics and Tools for Measuring Construction Productivity: Technical and Empirical Considerations. NIST Spec. Publ. 1101. National Institute of Standards and Technology, Gaithersburg.

[25] Bröchner, J. and Olofsson, T. (2012) Construction Productivity Measures for Innovation Projects: Case Study. Journal of Construction Engineering and Management, 138, 670-677. http://dx.doi.org/10.1061/(ASCE)CO.1943-7862.0000481

[26] Martino, J.P. (2003) A Review of Selected Recent Advances in Technological Forecasting. Technological Forecasting \& Social Change, 70, 719-733. http://dx.doi.org/10.1016/S0040-1625(02)00375-X

[27] Armstrong, J.S. (2006) Findings from Evidence-Based Forecasting: Methods for Reducing Forecast Error. International Journal of Forecasting, 22, 583-598. http://dx.doi.org/10.1016/j.ijforecast.2006.04.006

[28] Ewing, R. and Bartholomew, K. (2009) Comparing Land Use Forecasting Methods: Expert Panel versus Spatial Interaction Model. Journal of the American Planning Association, 75, 343-357. http://dx.doi.org/10.1080/01944360902956296

[29] Helmer, O. (1968) Analysis of the Future: The Delphi Method, Technological Forecasting for Industry and Government-Methods and applications. Prentice-Hall, Englewood Cliffs.

[30] Powell, C. (2003) The Delphi Technique: Myths and Realities. Journal of Advanced Nursing, 41, 376-382. http://dx.doi.org/10.1046/j.1365-2648.2003.02537.x

[31] CEN (2012) Sustainability of Construction Works-Assessment of Buildings Part 4: Framework for the Assessment of Economic Performance. EN 15643-4. European Committee for Standardization, Brussels, 18-19.

[32] Larsson, C. and Sjöstedt, H. (2010) Efficiency Measures for Buildings-A Model for Efficiency Measuring Applied on Outer Walls of Apartment Buildings (in Swedish). ISRN lutvdg7tvbp-10/5401-SE, Construction Management, Lund University, Lund.

[33] Pemsel, S. and Müller, R. (2012) The Governance of Knowledge in Project-Based Organizations. International Journal of Project Management, 30, 865-876. http://dx.doi.org/10.1016/j.ijproman.2012.02.002

[34] Kale, S. and Karaman, E.A. (2011) Evaluating the Knowledge Management Practices of Construction Firms by Using Importance-Comparative Performance Analysis Maps. Journal of Construction Engineering and Management, 137, 1142-1152. http://dx.doi.org/10.1061/(ASCE)CO.1943-7862.0000369 
[35] Pemsel, S., Widén, K. and Hansson, B. (2010) Managing the Needs of End-Users in the Design and Delivery of Construction Projects. Facilities, 28, 17-30. http://dx.doi.org/10.1108/02632771011011378

[36] Kendall, S. and Teicher, J. (2000) Residential Open Building. Spon, London.

[37] Habraken, N.J. (1972) Supports, an Alternative to Mass Housing. The Architectural Press, New York.

[38] Juvander, K., Franzén, M., Adolfphsson, P.B. and Balgård, S. (2000) Arkitektur och liv i kvarteret Garnisonen [Architecture and Life in the Garrison Quarter]. Raster förlag, Stockholm. (in Swedish)

[39] KBS (1990) Neutral Building Product Model—System Description. Swedish Construction Authority Board Report. T: 1231990-11, Stockholm. (in Swedish)

[40] Kunz, J. and Fischer, M. (2011) Virtual Design and Construction: Themes, Case Studies and Implementation Suggestions. Center for Integrated Facility Engineering, Working Paper No. 097, Stanford University, 2-3.

[41] Bygganalys (2010) Construction Costs for Office Buildings-Compilation for Construction Innovation. Bygganalys, Stockholm.

[42] Senaratne, S. and Sexton, M.G. (2009) Role of Knowledge in Managing Construction Project Change. Engineering, Construction and Architectural Management, 16, 186-200. http://dx.doi.org/10.1108/09699980910938055

[43] Dubois, A. and Gadde, L.E. (2002) The Construction Industry as a Loosely Coupled System: Implications for Productivity and Innovation. Construction Management and Economics, 20, 621-631. http://dx.doi.org/10.1080/01446190210163543

[44] Hossain, L. (2009) Communication and Coordination in Construction Projects. Construction Management and Economics, 27, 25-39. http://dx.doi.org/10.1080/01446190802558923 
Scientific Research Publishing (SCIRP) is one of the largest Open Access journal publishers. It is currently publishing more than 200 open access, online, peer-reviewed journals covering a wide range of academic disciplines. SCIRP serves the worldwide academic communities and contributes to the progress and application of science with its publication.

Other selected journals from SCIRP are listed as below. Submit your manuscript to us via either submit@scirp.org or Online Submission Portal.
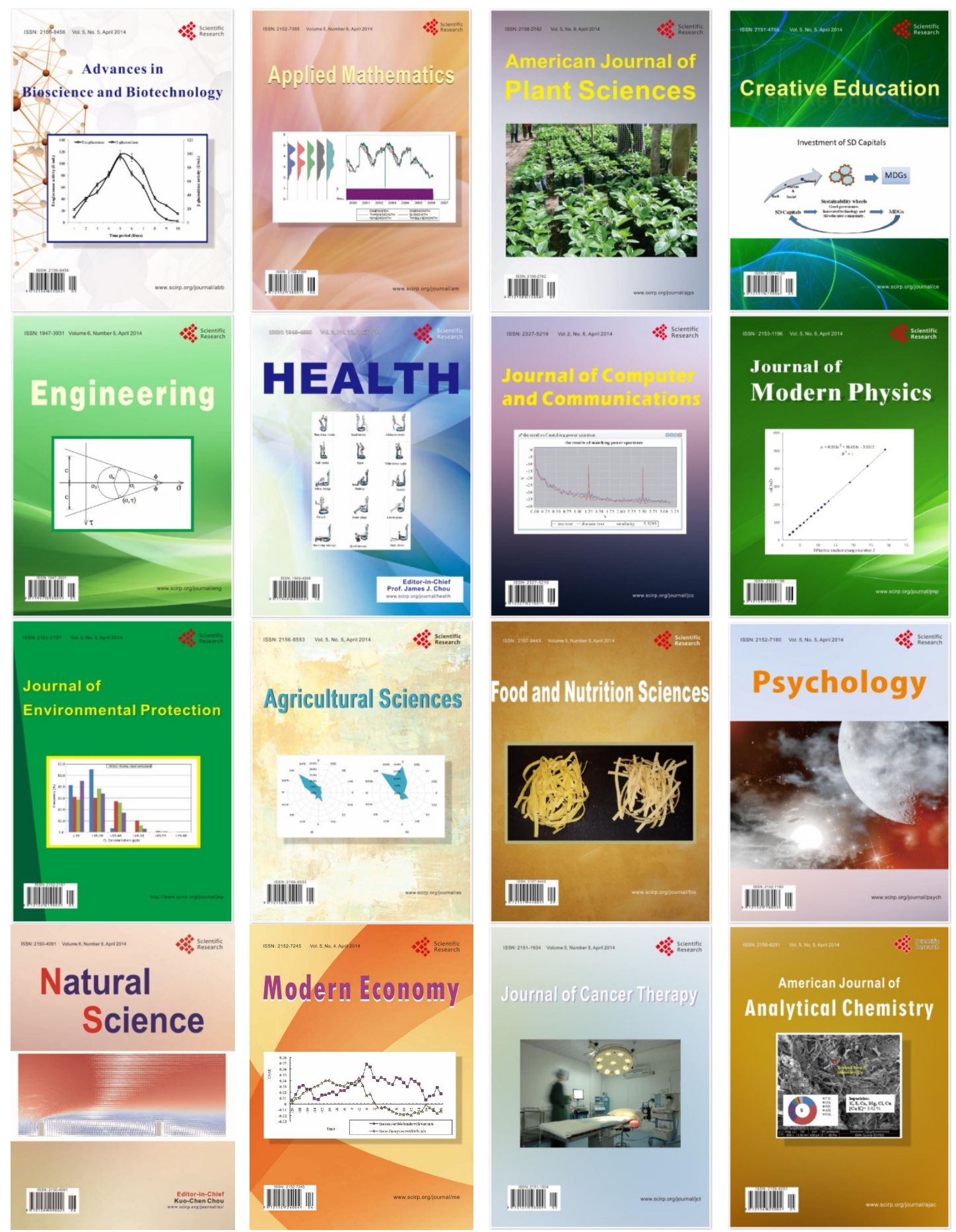